\title{
JPSE
}

(Journal of Physical Science and Engineering)

\section{Reconstruction of Bandung Groundwater Basin Model Using Schlumberger Configuration Geoelectric Method}

\begin{tabular}{l}
\hline Received \\
20 April 2021 \\
Revised \\
31 July 2021 \\
Accepted for Publication \\
17 October 2021 \\
Published \\
22 October 2021
\end{tabular}

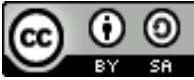

This work is licensed under a Creative Commons Attribution ShareAlike 4.0 ShareAlike 4.0

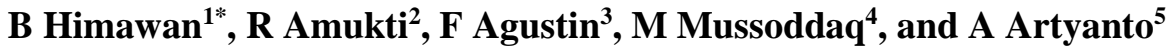 \\ 1. Department of Mining Engineering, Faculty of Engineering, Universitas Muhammadiyah \\ Tasikmalaya, Jl. Tamansari Mulyasari, Tasikmalaya, 46196, Indonesia. \\ 2. Center for Deep-Sea Research, Indonesian Institute of Sciences, Jl. Y. Syaranamual Guru-Guru, \\ Ambon, 97233, Indonesia. \\ 3. Department of Mining Engineering, Faculty of Engineering and Design, Institut Teknologi dan \\ Sains Bandung, Jl. Ganesha Boulevard, Bekasi, 17531, Indonesia \\ 4. Department of Geology Engineering, Faculty of Earth Science and Technology, Institut \\ Teknologi Bandung, Jl. Ganesha 10, Bandung, 40132, Indonesia. \\ 5. PT. Timah Tbk., Jl. Jenderal Sudirman 51, Pangkal Pinang, 33121, Indonesia.
}

*E-mail: bayuhimawan.geologist@gmail.com

\begin{abstract}
Bandung is a city with rapid industrial development and a dense population. It causes the need for clean water to be huge, so it impacts groundwater extraction on a large scale. The Bandung Basin, which is a good reservoir for groundwater, will be disturbed if conservation and monitoring efforts are not carried out in the presence of groundwater. This study focuses on reconstructing the groundwater model in the Bandung Basin using the Schlumberger geoelectric method. After taking and analyzing the data, it was found that the resistivity value of the location of the presence of groundwater is depicted into three groundwater basins, namely the Bandung-Soreang groundwater basin, the Lembang groundwater basin, and the Batujajar groundwater basin. Unfettered aquifers, relatively aquitard in nature, are in the upper layer of the coal sandstone, claystone and sandstone units. The confined aquifer in the sand unit is under the sandy claystone layer.
\end{abstract}

Keywords: Bandung basin, groundwater, geoelectric, resistivity, aquifer.

\section{Introduction}

Groundwater is an essential component in people's lives. Without groundwater with pristine water quality, many problems will occur, ranging from health to the community's economy [1]. Groundwater conditions are strongly influenced by the rate of population growth in the area [1], [2]. One of the areas with a very rapid pace of development in the development sector is the city of Bandung. This condition causes the need for clean water to be critical to be studied [1].

The quality and quantity of groundwater can decrease if taken massively and on a large scale without being balanced with environmental improvements [3]. It is more worrying when groundwater extraction is supported by development that ignores water catchment areas [4], [5]. The literature study that has been carried out provides data that there are 550 industries in the Bandung Basin and $80 \%$ of them are textile industries that require much groundwater as industrial material. This problem continues to cause land subsidence, especially in the Dayeuhkolot industrial area [1]. The development of residential and industrial areas that ignore water catchment is also a problem for the Bandung Basin. Every time it rains, which produces large runoff water does not enter the ground, it collects and causes flooding [1], [6]-[9].

In order to determine the presence of groundwater in the Bandung Basin, it is necessary to conduct research on the reconstruction of the Bandung City groundwater basin model. The geophysical method that can be optimized in this problem is the resistivity geoelectric method with the Schlumberger configuration. The method used to determine groundwater can use the Schlumberger configuration electricity. This method is potent to apply, for example, in the case of estimating groundwater distribution in Cokroaminoto Palopo [10], detection of groundwater in the Sam Ratulangi area [11], and water content analysis for landslide-prone areas in Olak Alen Village [12]. This study aims to determine the description of groundwater conditions in the city of Bandung. 


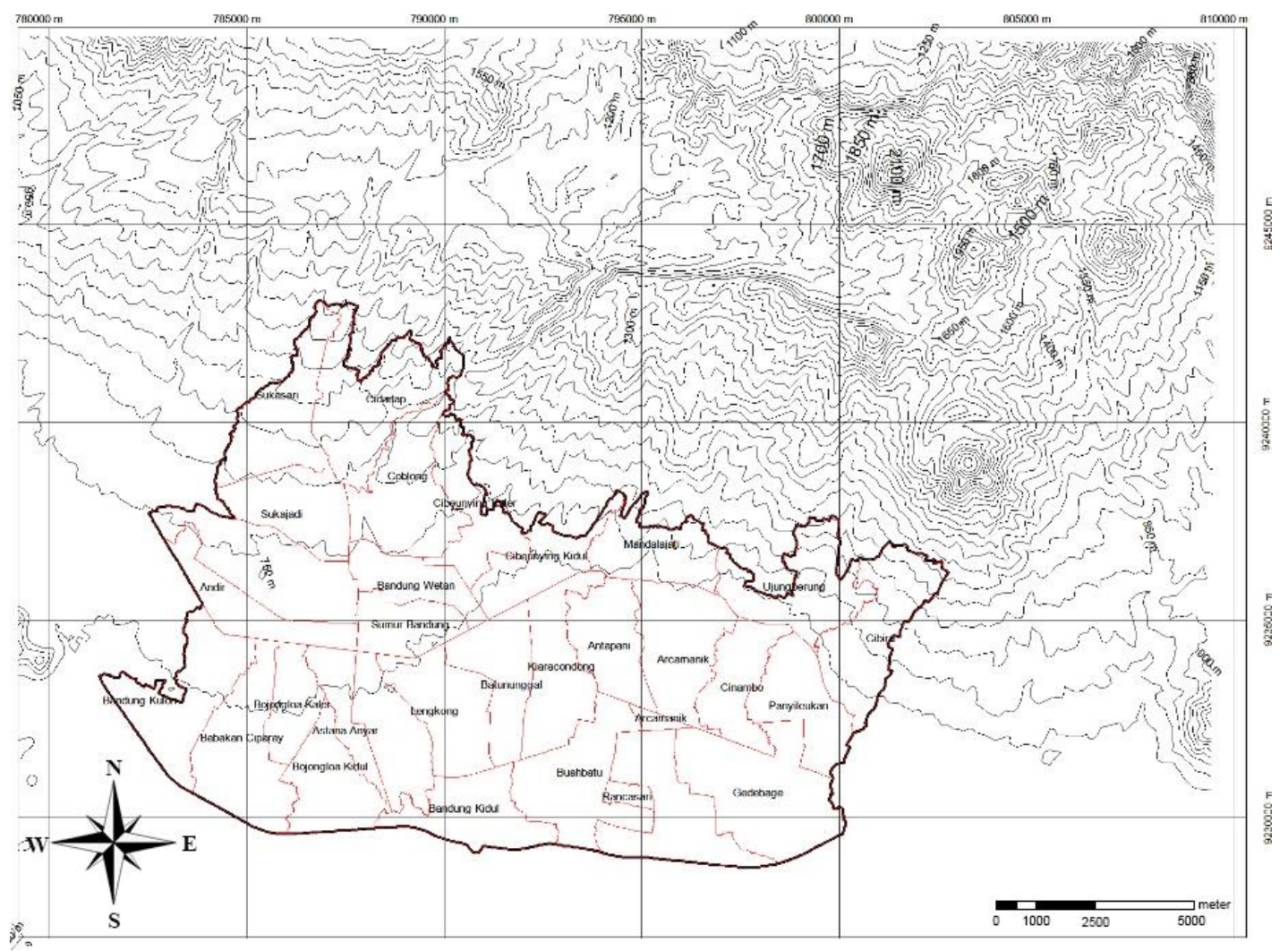

Figure 1. Map of research area.

\section{Method}

The study area is in the city of Bandung. Geographically, the city of Bandung is located at coordinates $107^{\circ} 33^{\prime} 39.24^{\prime \prime}$ to $107^{\circ} 44^{\prime} 19.25^{\prime \prime}$ east longitude and $6^{\circ} 58^{\prime} 03^{\prime \prime}$ to $6^{\circ} 50^{\prime} 25.88^{\prime \prime}$ south latitude [12]. Bandung is located at 675-1,050 meters above sea level, with the highest point in the north and the lowest point in the south. The morphology of Bandung City is divided into two stretches, which in the north is relatively hilly and the south is a plain area [12], [13], as shown in Figure 1.

The method used in this study is the resistivity method with the Schlumberger configuration. The differences in resistivity values for each type of rock and subsurface layers can be analyzed the differences between minerals, rocks, and groundwater below the surface [14]. The configuration used in this study is the geoelectric Schlumberger configuration. There are four electrodes used, two electrodes are potential electrodes (MN) and the other two are current injection electrodes (AB) [15][17]. The arrangement of the electrodes in the Schlumberger configuration can be seen in Figure 2.

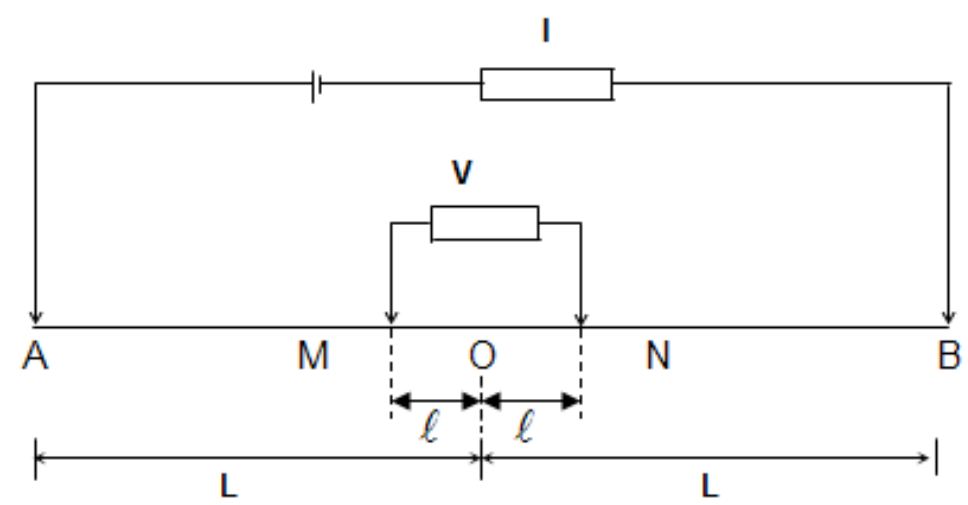

Figure 2. Schlumberger configuration. 


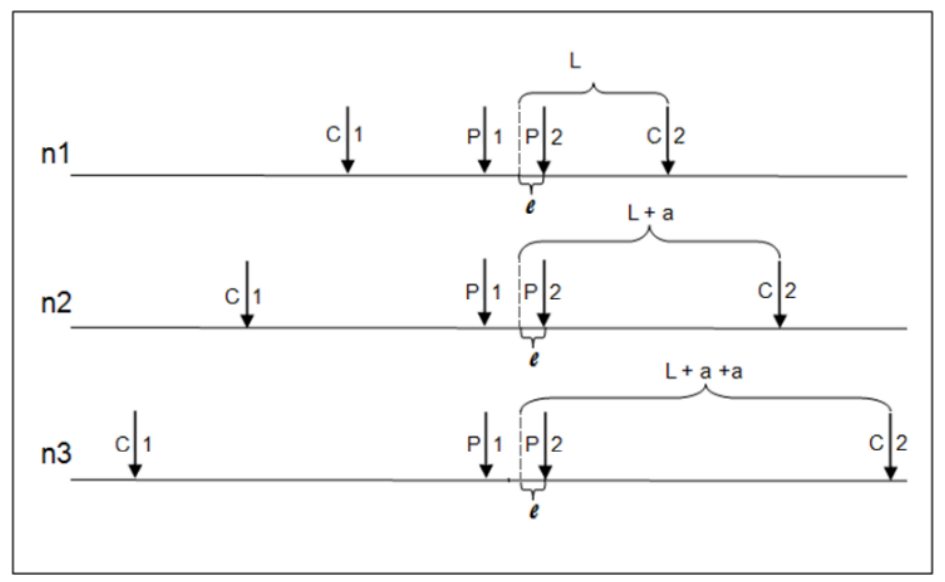

Figure 3. Schlumberger configuration electrode displacement.

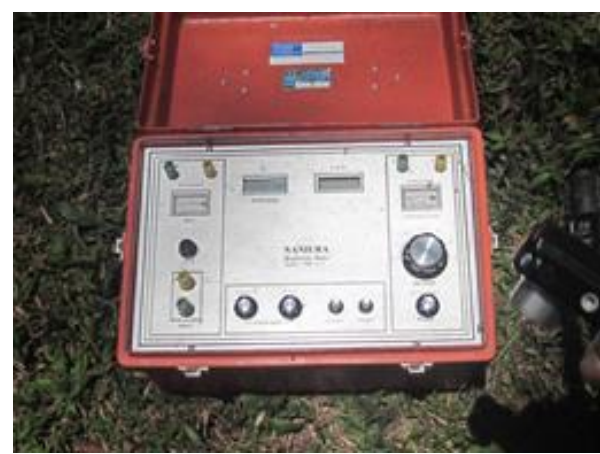

(a)

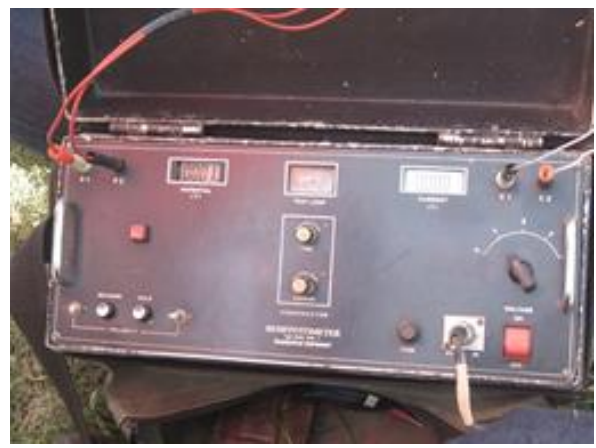

(b)

Figure 4. Resistivity meter (a) NANIURA and (b) EDAK.

The measurement of the Schlumberger electrode configuration is arranged as shown in Figure 3. The initial position of the electrode is placed at 0.5 meters from the measurement point for potential electrodes $\mathrm{P} 1$ and $\mathrm{P} 2(\mathrm{MN})$ and 1.5 meters from the zero point of measurement for current electrodes $\mathrm{C} 1$ and $\mathrm{C} 2 \mathrm{AB}$ ). Furthermore, the current electrode is widened to 300 meters and the potential electrode is widened to 50 meters. From this measurement, a subsurface image of \pm 200 meters will be obtained at each measurement point. The apparent resistivity value will be obtained from this data acquisition, which is carried out by the data processing process to obtain the actual resistivity and depth value. The equipment used in this research is resistivity with the brands Naniuran NRD and EDAK EXG-3 as shown in Figure 4.

\section{Result and Discussion}

Each depth's resistivity value at the geoelectrical measurement location is then interpreted as a rock lithology layer at the measurement spot. The interpretation process is carried out by correlating the processed data, the range of rock resistivity values, and the geology of the geoelectrical measurement area. The results of geoelectrical data processing in the form of resistivity values for each depth from several measurement points are combined to describe the continuity of the resistivity values to form layers. Furthermore, the type of rock in the layers formed is estimated throughout this process. The results of combining data from several geoelectric points and the interpretation results are shown in Figure 5.

The resistivity value from Figure 5 explains that the Bandung area forms one central basin. However, when viewed from the presence of groundwater in the basin, the Bandung area is divided into three groundwater basins. First, the Bandung-Soreang groundwater basin extends to Bandung Regency, Bandung City, Cimahi City, and Sumedang Regency. Second, Lembang groundwater basin. Third, Batujajar groundwater basin. Lembang and Batujajar groundwater basins are located in Bandung Regency. 


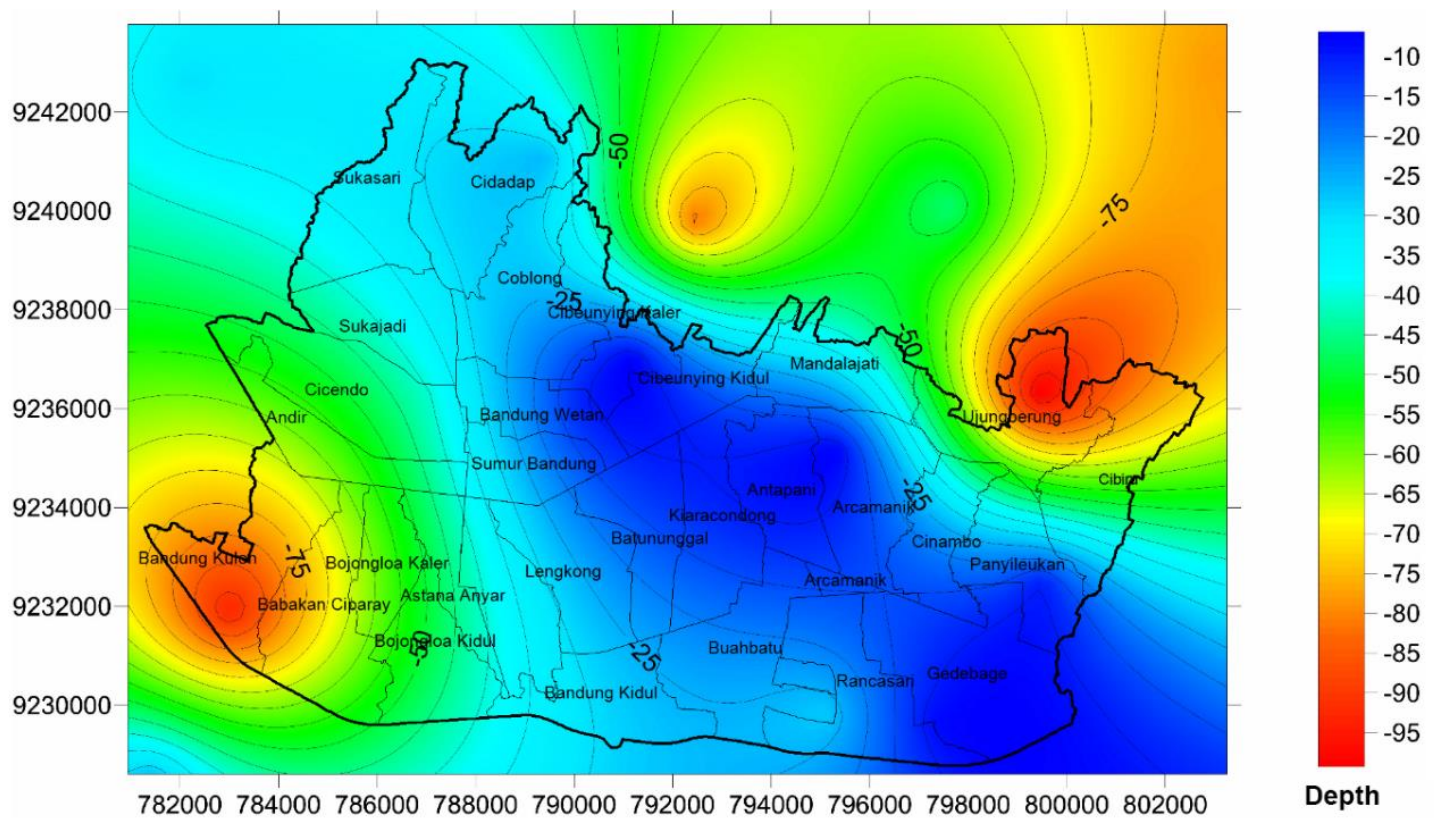

Figure 5. Groundwater distribution map based on geoelectric survey data and groundwater wells. Red to blue colours indicate differences in groundwater depth.

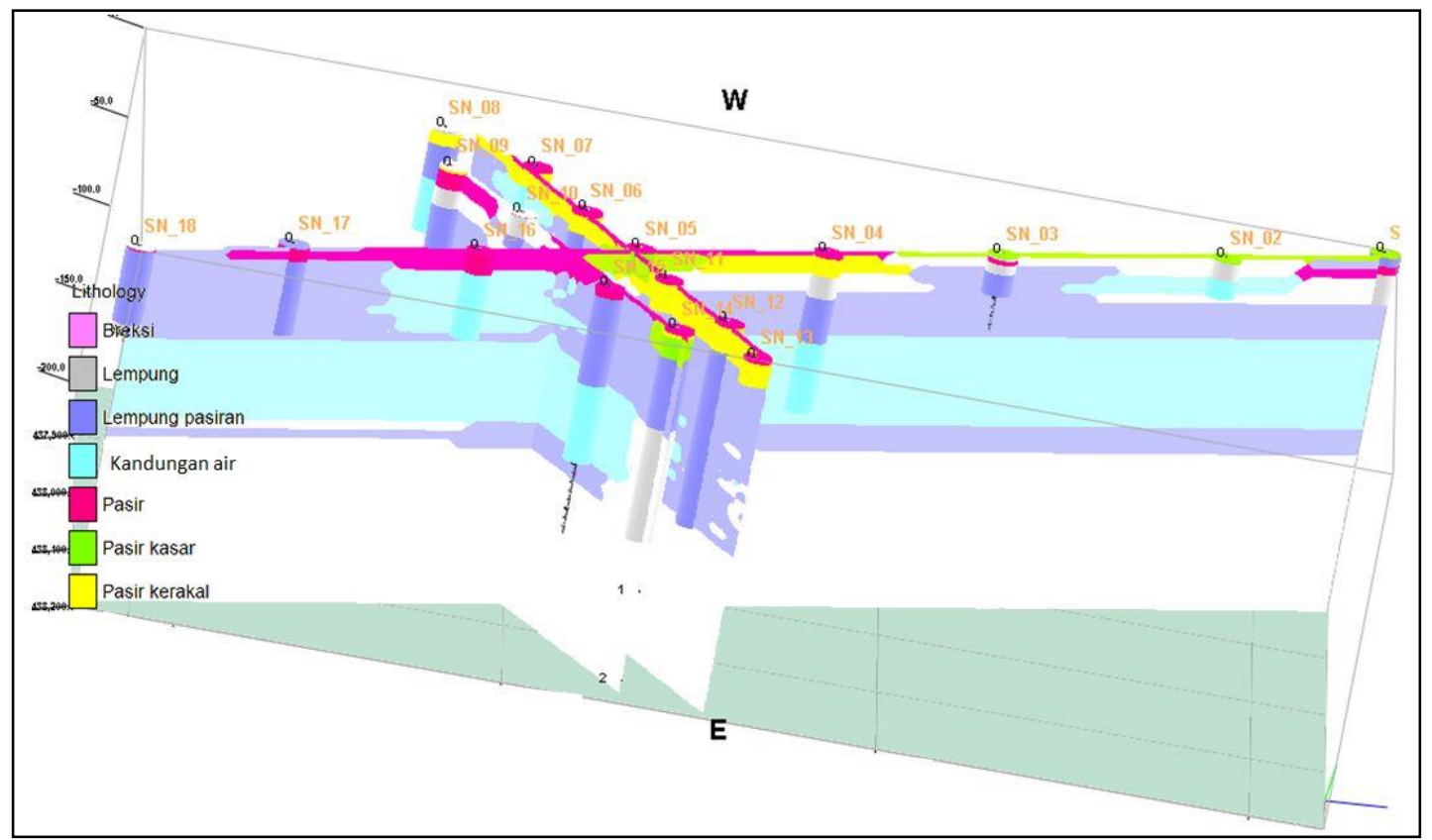

Figure 6. Block diagram of Bandung City aquifer interpretation analysis results.

Shallow groundwater in the Bandung area is generally located less than 40 meters from the ground surface, so local environmental conditions very easily influence it. This change in groundwater will be seen in dug wells [18], wherein in the rainy season, the groundwater level is always shallower than the groundwater level in the dry season [18], [19].

Based on the correlation results of the block diagram in Figure 6, it is known that the City of Bandung is geologically and hydro-geologically a high area in the west and lowers towards the east, where the eastern area is a border area with the sea [20]. Geologically, in general, the lithology from top to bottom is claystone and sandstone. Hydro-geologically, it can be divided into unconfined aquifers, relatively aquifer in the uppermost layer of the pebble-sand, claystone, and sandstone units. At the same time, the confined aquifer in the sandstone unit is below the clay-sand layer. 


\section{Conclusion}

Based on the comprehensive study of literature and analysis, it is concluded that the Bandung area forms one basin. However, when viewed from the presence of groundwater in the basin, the Bandung area is divided into three groundwater basins. First, the Bandung-Soreang groundwater basin extends to Bandung Regency, Bandung City, Cimahi City, and Sumedang Regency. Second, Lembang groundwater basin. Third, Batujajar groundwater basin. Lembang and Batujajar groundwater basins are located in Bandung Regency. In geological interpretation, in general, the lithology used as a confined aquifer in the sand unit is under the Sandy Claystone layer.

\section{Acknowledgment}

The authors would like to thank Mr Herlan P. W. and the team who have contributed to collecting field data.

\section{References}

[1] S. Sriyanti, D. Abdurrahman, N. F. Isniarno, R. Amukti, and S. Widayati, "Prediction of timelapse microgravity value based on groundwater change map in 2003-2010 at Dayeuhkolot industrial area, Bandung," in J. Phys.: Conf. Ser., vol. 1375, no. 1, p. 012045, 2019, doi: 10.1088/1742-6596/1375/1/012045.

[2] F. Yulianto, N. Suwarsono, S. Sulma, and M. R. Khomarudin, "Observing the inundated area using Landsat-8 multitemporal images and determination of flood-prone area in Bandung basin," Int. J. Remote Sensing and Earth Sci. (IJReSES), vol. 15, no. 2, pp. 131-140, 2019, doi: 10.32679/jsda.v17i1.654.

[3] I. Maliga, C. Asdak, and E. Y. Winata, "Analisis keberlanjutan pengendalian pencemaran air limbah domestik greywater menggunakan teknologi lahan basah buatan," J. Sumber Daya Air, vol. 17, no. 1, pp. 13-24, 2021, doi: 10.30536/j.ijreses.2018.v15.a3074.

[4] I. R. H. Sánchez, F. Castellanos, J. H. Barrientos, and S. I. B. Jiménez, "Gravimetric determination of storage coefficient and storage change of groundwater in an uncontrolled and unconfined aquifer," Natural Resources Res., pp. 1-12, 2021, doi: 10.1007/s11053-021-099047.

[5] A. Susanto, A. Kharis, and T. Khotimah, "Sistem informasi geografis pemetaan lahan pertanian dan komoditi hasil panen Kabupaten Kudus," J. Informatika Ahmad Dahlan, vol. 10, no. 2, p. 103299, 2016.

[6] F. Ridwan, M. Ardiansyah, and K. Gandasasmita, "Pemodelan perubahan penutupan/penggunaan lahan dengan pendekatan artificial neural network dan logistic regression (studi kasus: Das Citarum, Jawa Barat)," Buletin Tanah dan Lahan, vol. 1, no. 1, pp. 30-36, 2017.

[7] W. Ningrum and I. Narulita, "Deteksi perubahan suhu permukaan menggunakan data satelit landsat multi-waktu studi kasus cekungan Bandung," J. Teknol. Lingkung., vol. 19, no. 2, pp. 145-154, 2018.

[8] A. Pratama, D. E. Irawan, A. Susanto, and R. D. W. Ardi, "Influence of lithology and slope gradient to infiltration of the Mount Malabar, West Java," in IOP Conf. Ser.: Earth and Environ. Sci., vol. 29, no. 1, p. 012025, 2016, doi: 10.1088/1755-1315/29/1/012025.

[9] A. Purwoarminta, R. F. Lubis, and R. Maria, "Imbuhan air tanah buatan untuk konservasi cekungan air tanah Bandung-Soreang," RISET Geol. Pertambangan, vol. 29, no. 1, pp. 65-73, 2019, doi: 10.14203/risetgeotam2019.v29.1004.

[10] R. H. Manrulu, A. Nurfalaq, and I. D. Hamid, "Pendugaan sebaran air tanah menggunakan metode geolistrik resistivitas konfigurasi wenner dan schlumberger di kampus 2 Universitas Cokroaminoto Palopo," J. Fis. Flux, vol. 15, no. 1, pp. 6-12, 2018, doi: 10.20527/flux.v15i1.4507.

[11] H. T. Saranga and S. H. Tongkukut, "Deteksi air tanah menggunakan metode geolistrik resistivitas konfigurasi wenner-schlumberger di masjid kampus Universitas Sam Ratulangi dan sekitarnya," Jurnal MIPA, vol. 5, no. 2, pp. 70-75, 2016, doi: 10.35799/jm.5.2.2016.12963.

[12] M. Aisyah, W. Utama, and W. Lestari, "Analisis daerah rawan bencana tanah longsor berdasarkan zona water content di Olak Alen Kecamatan Selorejo, Blitar," J. Tek. ITS, vol. 6, no. 2, pp. C122-C124, 2017, doi: 10.12962/j23373539.v6i2.24902. 
[13] E. Kumalajati, "Menentukan arahan fungsi lahan daerah aliran sungai noelmina dengan aplikasi sistem informasi geografis (SIG)," ForestSains, vol. 14, no. 2, pp. 85-90, 2017.

[14] A. Nurfalaq, A. Nawir, R. H. Manrulu, and E. P. Umar, "Identifikasi akuifer daerah Pallantikang Kabupaten Jeneponto dengan metode geolistrik," J. Fis. Flux, vol. 15, no. 2, pp. 117-127, 2018, doi: $10.20527 / f l u x . v 15 i 2.5158$.

[15] M. Muhardi, F. Faurizal, and W. Widodo, "Analisis pengaruh intrusi air laut terhadap keberadaan air tanah di Desa Nusapati, Kabupaten Mempawah menggunakan metode geolistrik resistivitas," Indonesian Journal of Applied Physics, vol. 10, no. 2, pp. 89-96, 2020.

[16] S. Sohibun, "Aplikasi metode geolistrik konfigurasi schlumberger untuk mengidentifikasi lapisan air tanah di Desa Ulak Patian Rokan Hulu Riau," J. Fis. Flux., vol. 16, no. 1, pp. 54-60, 2019, doi: 10.20527/flux.v16i1.5651.

[17] A. N. Faris, D. A. Suaidi, S. Sutrisno, M. F. R. Hasan, and A. B. Broto, "Identification of aquifers distribution using geoelectric-resistivity method with schlumberger configuration in Gedangan Village, Malang Regency," Natural B, J. Health and Environ. Sci., vol. 5, no. 1, pp. 28-34, 2019.

[18] F. Saputra, S. A. Baskoro, S. Supriyadi, and N. Priyantari, "Aplikasi metode geolistrik resistivitas konfigurasi wenner dan wenner-schlumberger pada daerah mata air panas Kali Sengon di Desa Blawan-Ijen," BERKALA SAINSTEK, vol. 8, no. 1, pp. 20-24, 2020, doi: 10.19184/bst.v8i1.11991.

[19] M. A. Syam, K. Sasmito, A. M. Ghifary, and G. D. Lambe, "Geologi dan identifikasi akuifer dengan metode geolistrik konfigurasi dipole-dipole daerah Bhuana Jaya, Kecamatan Tenggarong Seberang, Kalimantan Timur," J. Tek. Geol.: J. Ilmu Pengetahuan dan Teknol., vol. 4, no. 1, 2021.

[20] A. R. Hakim and H. Hairunisa, "Pemetaan akuifer di daerah Bima untuk inventarisasi dalam pengelolaan sumberdaya air tanah secara berkelanjutan," KONSTAN-J. Fis. Pendidik. Fis., vo. 3, no. 2, pp. 74-84, 2018, doi: 10.20414/konstan.v3i2.11. 